\title{
Penggunaan Instagram sebagai Media Komunikasi Pemasaran untuk Membangun Brand Awareness saat Pandemi Covid-19
}

\author{
https://doi.org/10.25008/parahita.v1i2.49 \\ Ira Dasuki ${ }^{1}$, Umaimah Wahid ${ }^{2}$ \\ ${ }^{1,2}$ Universitas Budi Luhur \\ J1. Raya Ciledug Petukangan Utara, Kebayoran Lama Jakarta 12260 - Indonesia \\ "Korespondensi: iradasuki@gmail.com
}

\begin{abstract}
Abstrak - Pandemi Covid-19 mengharuskan masyarakat melakukan kegiatan di rumah dan menjaga jarak sosial (social distancing) sesuai dengan anjuran pemerintah. Hal tersebut telah mengubah pola kehidupan masyarakat di berbagai bidang dan membuat para pelaku usaha berpikir keras dalam menjalankan usahanya. Pada sisi lain, pandemi membuka kesempatan sebuah brand untuk memenuhi kebutuhan komuniksi pemasarannya dengan menggunakan sosial media Instagram untuk membangun brand awareness seperti yang dilakukan produk Thule. Tujuan dari penelitian ini adalah untuk mengetahui strategi komunikasi pemasaran dalam membangun Brand Awareness saat pandemi Covid19. Penelitian ini menggunakan pendekatan deskriptif kualitatif. Hasil dari penelitian ini adalah, membuat konten di akun bisa digunakan sebagai media komunikasi pemasaran dalam membangun Brand Awareness saat pandemi Covid-19.

Kata Kunci: Brand awareness, social media marketing, covid-19
\end{abstract}

\section{PENDAHULUAN}

Semakin meningkatnya angka penularan virus Covid-19 di Indonesia membuat pemerintah mengambil kebijakan menerapkan social distancing untuk mengurangi kegiatan di luar rumah dan interaksi dengan orang lain secara langsung (Papdi, Simposium, 2020). Kebijakan itu membuat interaksi secara langsung harus dihindari dan menerapkan work from home untuk berbagai kegiatan. Kebijakan yang diambil ini dipercaya dapat mengurangi penularan virus Covid-19 yang telah menyebar di hampir 140 negara (Gu, Han, \& Wang, 2020). Untuk mendukung kebijakan pemerintah tersebut, brand Thule melakukan branding merek menggunakan media sosial Instagram demi mengurangi kontak langsung dengan banyak orang.

Merek adalah bagian terpenting dari suatu produk yang ingin memasuki pasar. Merek dapat menjadi ciri khas atau pembeda dari suatu produk. Menurut Tjipjono (2008: 40), brand awareness merupakan kemampuan pemakai barang produksi atau jasa untuk mengidentifikasi sebuah merek. Brand Awareness berkenaan dengan aspek-aspek kesadaran sebuah merek, seperti seberapa mudah sebuah merek diingat dan dikenali dalam berbagai situasi. Kondisi di mana seorang pembeli potensial mampu mengetahui dan mengingat kembali sebuah merek adalah sebuah bagian dari kategori produk disebut dengan kesadaran merek (Aaker, 1991:61).

Perkembangan teknologi informasi dan komunikasi begitu pesat semenjak kemunculan internet khususnya media sosial. Media sosial telah menjadi gaya hidup dalam berbagi interaksi dan diskusi antarkomunitas. Interaksi yang awalnya bersifat vertikal menjadi horizontal; dari satu arah menjadi dua arah; dari "one to many" menjadi "many to many"; dari "broadcasting" menjadi "engagement" dan "permission-based".

Dengan perubahan-perubahan tersebut, pendekatan kepada konsumen pun juga harus diubah, salah satunya melalui pemanfaatan media sosial yang menitikberatkan pada bagaimana menciptakan komunikasi dan engagement dengan konsumen. Dengan memanfaatkan media sosial secara tepat, dapat menjadi salah satu media komunikasi yang baik bagi perusahaan dan konsumennya. Hal ini sejalan dengan generasi milenial yang saat ini berada di usia produktif dan memiliki gaya hidup yang akrab dengan media sosial dan internet. Dengan adanya 
fenomena ini, perusahaan berbondong-bondong melakukan ekspansi pada strategi marketing untuk memanfaatkan media sosial.

Media sosial menurut Philip Kotler dan Kevin Keller (2012; 568), merupakan sarana bagi konsumen untuk berbagi informasi teks, gambar, audio, dan video dengan satu sama lain dan dengan perusahaan dan sebaliknya. Media sosial pada saat ini sangat berperan penting dalam mendongkrak kemajuan bisnis.

Instagram adalah aplikasi yang digunakan untuk mengunggah dan berbagi foto kepada pengguna lainnya. instagram terdiri dari kata "insta" yang berasal dari kata "instan", seperti kamera polaroid yang pada masanya dikenal dengan sebutan "foto instan". Instagram juga dapat menampilkan foto-foto secara instan, seperti tampilan polaroid. Sedangkan kata "gram" berasal dari kata "telegram", dimana cara kerja telegram sendiri adalah untuk mengirimkan informasi kepada orang lain dengan cepat.

Perbedaannya, instagram menggunakan jaringan internet, sehingga informasi yang ingin disampaikan dapat diterima realtime (Diamond, 2015). Saat ini, terdapat banyak pengguna akun Instagram yang memanfaatkan aplikasi ini untuk memasarkan dan menjual produk/jasa, melalui share foto-foto produk pemasar. Dalam studi yang dilakukan oleh Simply Measured, terungkap bahwa 54\% perusahaan brand ternama dunia kini menggunakan Instagram (Baihaki, 2012). Tak terkecuali pada brand Thule yang dikelola oleh Bags City di Indonesia, memanfaatkan sosial media Instagram sebagai media komunikasi dalam meningkatkan brand awareness.

Bags City adalah perusahaan yang bergerak di bidang retail koper, tas, dan aksesoris perjalanan yang telah beroperasi sejak tahun 1992. Dengan menjual berbagai merk kelas dunia seperti Lojel, Thule, Traveler's Choice, Bagasi, Travel Blue, dan Case Logic. Bags City memiliki beberapa store di berbagai kota: Jakarta, Bandung, Surabaya dan Bali. Brand Thule tersedia di seluruh store Bags City maupun di berbagai depstore, seperti Sogo, Centro, Metro, Seibu, Lotte Love, Central dan Lafayette.

Thule didirikan di Swedia pada tahun 1942. Sejak saat itu, thule telah membuat bisnis untuk membawa konsumennya lebih dekat dengan dunia dan gaya hidup (lifestyle) dengan menciptakan berbagai koleksi seperti Luggage, Backpacks, Bike Bags, Laptop, Tablet \& Phone Cases serta Camera Bags dan Cases.

Brand Thule sudah cukup terkenal di wilayah store offline, namun di dunia online belum cukup terkenal. Seperti dikatakan Philip Kotler, Hermawan Kartajaya dan Iwan Setiawan dalam buku Marketing 4.0, kombinasi interaksi secara online dan offline dibutuhkan untuk saling melengkapi. Hal ini diperlukan untuk menyentuh konsumen agar mendapatkan pelayanan yang memuaskan dari produk yang ditawarkan. Kegiatan pemasaran dan menciptakan kesadaran merek harus disesuaikan dengan perubahan alami dari jalur pelanggan dalam ekonomi digital, sehingga terbentuk konvergensi antara media komunikasi online dan offline.

Strategi membangun kesadaran merek melalui media baru, yaitu media sosial Instagram ini memang sedang marak di kalangan pelaku bisnis Indonesia. Dengan memanfaatkan fiturfitur yang disediakan Instagram, pemilik akun dapat dengan mudah mengelola akun sesuai dengan yang diinginkan. Dengan melihat kesempatan yang bagus dari pemanfaatan Instagram sebagai komunikasi pemasaran dalam membangun brand awareness, menjadikan Bags City memilih cara tersebut untuk membantu meningkatkan kesadaran merek dari konsumen karena proses penyebaran informasi yang sangat cepat. Setelah dikenal, banyak konsumen yang dengan mudah berinteraksi melalui akun Instagram tanpa harus berkunjung langsung ke Store offline Bags City.

\section{KERANGKA TEORI}

Covid-19 merupakan pandemi yang menyerang seluruh negara. Masyarakat Indonesia 
wajib melakukan social distancing (jaga jarak) dan pemerintah melakukan pembatasan sosial berskala besar (PSBB) tanpa terkecuali termasuk perusahaan. Dampak dari kebijakan itu sangat berat bagi perusahaan karena harus menutup produksi dan merumahkan karyawan.

Salah satu kiat yang efektif untuk diterapkan pada masa pandemi ini adalah memaksimalkan komunikasi pemasaran dan meningkatkan kesadaran merek, mengingat semakin banyak masyarakat bekerja dari rumah (work from home). Dengan demikian, peluang untuk memaksimalkan upaya meningkatkan brand awareness melalui internet akan lebih mudah, karena penggunaan internet pada saat pandemi Covid-19 meningkat pesat. Dilansir dari CNN indonesia, terjadi peningkatan yang signifikan terhadap pengguna internet di masa pandemi ini yaitu sampai 40 persen.

Menyikapi kondisi seperti ini perusahaan harus melakukan perombakan strategi komunikasi pemasaran sebagai upaya untuk meningkatkan brand awareness. Strategi yang dimaksud adalah penyampaian pesan melalui konten traveling di tengah pandemi Covid-19 yang dibuat oleh perusahaan bekerjasama dengan beberapa influencer melalui media sosial instragram untuk menghubungkan konsumen dengan produsen.

Dasar utama yang mendasari penelitian ini adalah komunikasi yang menjadi tumpuan bagaimana proses kesadaran merek timbul. Menurut M. Roger ( dalam Dedy Mulyana, 2009: 8), komunikasi adalah proses suatu ide dialihkan dari sumber kepada suatu penerima, dengan maksud mengubah tingkah laku mereka. Menurut Richard West (2017 : 5), komunikasi adalah proses sosial di mana individu menggunakan simbol untuk membangun dan menginterpretasikan makna dalam lingkungan mereka.

Sementara itu Harsono Suwardi menyatakan dasar dari pemasaran adalah komunikasi, dan pemasaran bisa powerful jika dipadukan dengan komunikasi yang efektif dan efisien. Bagaimana menarik konsumen atau khalayak menjadi aware, kenal dan mau membeli suatu produk atau jasa melalui saluran komunikasi bukan sesuatu yang mudah (Prisgunanto, 2006:7).

Menurut Kotler dan Keller (2012:498), komunikasi pemasaran adalah sarana yang digunakan perusahaan untuk menginformasikan, membujuk, dan mengingatkan konsumen baik secara langsung maupun tidak langsung tentang produk dan merek yang mereka jual. Komunikasi pemasaran memegang peranan sangat penting bagi pemasar. Tanpa komunikasi, konsumen maupun masyarakat secara keseluruhan tidak akan mengetahui keberadaan produk di pasar.

Penentuan siapa saja yang menjadi sasaran komunikasi akan sangat menentukan keberhasilan komunikasi. Dengan penentuan sasaran yang tepat, proses komunikasi akan berjalan efektif dan efisien (Sutisna, 2002:268). Komunikasi pemasaran (marketing communication) adalah sarana di mana perusahaan berusaha menginformasikan, membujuk, dan mengingatkan konsumen secara langsung maupun tidak langsung tentang produk dan merek yang dijual.

Komunikasi pemasaran juga melaksanakan banyak fungsi bagi konsumen. Komunikasi pemasaran dapat memberitahu atau dapat memperlihatkan kepada konsumen bagaimana dan mengapa produk itu digunakan, oleh orang macam apa, serta dimana dan kapan. Komunikasi pemasaran memungkinkan perusahaan menghubungkan merek mereka dengan orang, tempat, acara, merek, pengalaman, perasaan, dan hal lainnya. Hal ini tentunya salah satu upaya yang bertujuan untuk meningkatkan kesadaran suatu merek di masyarakat.

Dunia pemasaran kini terus berkembang di era digital dan melahirkan pendekatan pemasaran baru yaitu pemasaran 4.0, suatu pendekatan pemasaran yang menggabungkan interaksi online dan offline antara perusahaan dan pelanggan. Selain itu juga memadukan gaya dan substansi dalam membangun merek, dan akhirnya melengkapi konektivitas mesin ke mesin dengan sentuhan manusia ke manusia untuk memperkuat keterlibatan pelanggan.

Pemasaran 4.0 membantu pemasar beralih ke ekonomi digital yang mendefinisikan ulang konsep kunci dari pemasaran. Pemasaran digital dan pemasaran tradisional dimaksudkan untuk 
dipadukan dengan tujuan mendapatkan advokasi pelanggan (Philip Kottler dalam Kertajaya dan Setiawan 2018:43).

Sebelum jadi pemasaran 4.0 lebih dulu dikenal pemasaran 1.0 yang berfokus pada produk atau disebut product centric era. Di mana para produsen membuat produk yang bagus kemudian diarahkan sesuai keinginannya dan tidak memperhatikan keiginan konsumen.

Pemasaran 2.0 adalah pemasaran yang berfokus pada customer centric era. Dalam hal ini produsen mencari konsumen kemudian mempelajari need and want konsumen. Setelah itu produsen membuat produknya.

Pemasaran 3.0 adalah pemasaran yang berfokus pada kemanusiaan human centric era. Disini produsen memperhatikan produk dan konsumen. Kegiatan pemasaran diarahkan tidak hanya fungsional dan emosional tetapi lebih ke spiritual. Sehingga pelaku usaha lebih memperhatikan aktifitas kemanusiaan dan nilai-nilai universal. Dan yang terbaru adalah pemasaran 4.0. (Philip Kottler dalam Kertajaya dan Setiawan 2018:43).

Dalam pemasaran 4.0, digital marketing tidak benar-benar menggantikan pemasaran tradisional. Sebaliknya, keduanya hadir bersama atau yang lebih dikenal dengan coexist. Keduanya saling mengisi peran satu sama lain, khusunya dalam perjalanan pelanggan atau customer path. Pada tahap awal interaksi antara perusahaan dan pelanggan, pemasaran tradisional memainkan peran penting dalam membangun kesadaran dan minat.

Saat interaksi tersebut berlanjut, menjadikan pelanggan menuntut hubungan yang lebih erat dengan perusahaan. Pemasaran digital menjadi sangat penting karena mendorong tindakan dan penganjuran. Selain itu pemasaran digital lebih akuntabel daripada pemasaran tradisional yang lebih memperkarsai interaksi dengan pelanggan (Philip Kottler dalam Kertajaya dan Setiawan 2018:49).

Sementara itu, pemasaran konten (Content Marketing) merupakan strategi pemasaran dengan cara menghasilkan konten yang memiliki tujuan untuk memberi informasi kepada calon konsumen yang bersifat persuasif atas produk yang dipasarkan. Persuasif tersebut dapat berupa ajakan dengan cara memberi alasan dan prospek yang baik untuk menyakinkan konsumen.

Strategi pemasaran ini memfokuskan pada pembuatan dan pendistribusian konten yang bernilai, relevan, dan konsisten agar dapat menarik dan mepertahankan audiens yang sudah ditetapkan dengan jelas dan secara keseluruhan untuk mendorong tindakan konsumen yang dapat menghasilkan keuntungan. Dengan demikian fungsi dan tujuan pemasaran konten adalah untuk mengedukasi konsumen dan menjadi jembatan yang menghubungkan antara produsen dan konsumen untuk membentuk sebuh proses komunikasi yang menyenangkan melalui informasi konten yang dimiliki (Philip Kottler dalam Kertajaya dan Setiawan 2018:119).

Hal ini menjadikan arti dari pemasaran konten bukan sebagai strategi memasarkan produk atau jasa secara langsung, melainkan usaha penciptaan konten yang bertujuan mempengaruhi konsumen untuk melakukan pembelian. Penggunaan strategi pemasaran konten memiliki tujuan untuk menarik dan mempertahankan pelanggan dengan cara yang konsisten membuat dan mengurasi konten-konten bernilai dan relevan dengan maksud mengubah atau memperbaiki perilaku konsumen. Hal ini menjadikan proses berkelanjutan terbaik yang diintegrasikan ke dalam strategi pemasaran secara keseluruhan dan berfokus pada memiliki media bukan menyewakan media. Pada dasarnya pemasaran konten adalah sebuh seni berkomunikasi dengan pelanggan dan calon pelanggan tanpa harus menjual. Esensi dari strategi konten yang dilakukan adalah keyakinan bahwa pemilik bisnis menyampaikan informasi secara konsisten dan bernilai untuk para pembeli. Maka mereka akan memberikan timbal balik dengan bisnis dan juga kesetiaan (loyalty).

Menurut Raper Public Affairs, 80 persen dari pembuatan keputusan lebih memilih untuk mendapatkan informasi tentang perusahaan dari rangkaian artikel dibandingkan melalui iklan, 70 perseb menyebutkan pemasaran konten membuat mereka lebih dekat pada keputusan untuk 
mensposori sebuah perusahaan, sementara itu 60 persen mengatakan konten tentang perusahaan membantu mereka untuk memutuskan dengan lebih baik.

Pemasaran konten yang efektif mengharuskan pemasar menciptakan konten asli secara internal atau memilih dari sumber eksternal. Selain itu para pemasar juga harus mendistribusikan kontennya melalui saluran atau media yang dipilih. Pada pemasaran konten hal yang paling umum adalah melaksanakan prouksi dan distribusi konten secara langsung tanpa melakukan kegiatan pra produksi dan pasca distribusi yang tepat. Berikut delapan langkah dalam melakukan pemasaran konten yang harus diterapkan oleh pemasar (Philip Kottler dalam Kertajaya dan Setiawan 2018:124-134):

(1) Menetapkan Tujuan. Sebelum memulai perjalanan pemasaran konten, pemasar harus mendefinisikan tujuan secara jelas. Jika tanpa tujuan yang tepat pemasar dapat tersesat ketika mencurahkan diri dalam penciptaan konten dan distribusi. Tujuan pemasar harus selaras dengan tujuan bisnis secara keseluruhan dan diterjemahkan menjadi metric kunci yang akan mengevaluasi pemasaran kontennya;

(2) Pemetaan Target Pasar. Begitu tujuan sudah ditetapkan maka pemasar harus menentukan kelompok mana yang ingin mereka fokuskan. Menetapkan sub bagian kelompok tertentu dapat membantu pemasar menciptakan konten yang lebih tajam dan lebih dalam sehingga memberikan kontribusi pada penceritaan efektif tentang merek;

(3) Pengagasan dan Perencanaan Konten. Dalam mencari gagasan tentang konten yang akan diciptakan harus melalui perencanaan yang tepat. Dengan mengkombinasikan tema yang relevan, format yang cocok, dan narasi yang solid akan memastikan terwujudnya konten yang sukses;

(4) Penciptaan Konten. Pemasar konten yang sukses mengetahui bahwa penciptaan konten bukanlah pekerjaan ringan. Penciptaan konten membutuhkan komitmen besar dalam hal waktu dan anggaran. Apabila konten tidak berkualitas tinggi, asli, dan kaya maka konten hanya akan menghamburkan waktu dan terkadang bisa menjadi boomerang bagi pemasar;

(5) Distribusi Konten. Pemasar harus memastikan bahwa konten mereka dapat ditemukan oleh konsumen melalui distribusi yang tepat. Terdapat tiga kategori besar saluran media yang digunakan pemasar koten yakni, media yang dimiliki, berbayar, dan diperoleh;

(6) Penguatan Konten. Kunci dalam mendapatkan distribusi media yang kuat adalah strategi penguatan konten. Dengan cara menjangkau orang-orang berpengaruh didalam suatu kelompok sehingga memungkinkan konten akan menjadi viral;

(7) Evaluasi Pemasaran Konten. Evaluasi terhadap pemasaran konten merupakan langkah dari pasca produksi. Hal ini mencakup pengukuran performa strategis maupun taktis. Secara strategis, pemasar harus mengevaluasi apakah strategi pemasaran konten mencapai tujuan penjualan dan merek yang ditetapkan pada langkah 1. Sehingga memiliki tujuan yang selaras dengan keseluruhan tujuan bisnis. Evaluasi ini sangat mudah dan dapat dipadukan dengan seluruh pengukuran performa merek. Secara taktis, pemasar harus mengevaluasi metric pemasaran konten kunci dengan bergantung pada pilihan format dan saluran media;

(8) Perbaikan Pemasaran Konten. Konten memiliki sifat yang dinamis, sehingga perbaikan pemasaran konten secara berkala dianggap sangat penting. Hal ini menjadikan pemasar untuk menentukan evaluasi dan horizon perbaikan dalam memutuskan kapan waktu untuk mengubah pendekatan pemasaran konten. Selain itu pemasaran konten butuh waktu untuk memberikan dampak dan membutuhkan kegigihan pada tingkat tertentu dalam konsistensi pelaksanaanya.

Sementara itu teori new media merupakan sebuah teori yang dikembangkan oleh Pierre Levi, yang mengemukakan bahwa media baru merupakan teori yang membahas mengenai perkembangan media. Dalam teori new media, terdapat dua pandangan, Pertama yaitu pandangan interaksi sosial, yang membedakan media menurut kedekatannya dengan interaksi tatap muka. Pierre Levy memandang world wide web (www) sebagai sebuah lingkungan 
informasi yang terbuka.

Fleksibel dan dinamis yang memungkinkan manusia mengembangkan orientasi pengetahuan yang baru. Pandangan kedua yaitu pandangan integrasi sosial, yang merupakan gambaran media bukan dalam bentuk informasi, interaksi, atau penyebarannya, tetapi dalam bentuk ritual, atau bagaimana manusia menggunakan media sebagai cara menciptakan masyarakat. Media bukan hanya sebuah instrumen informasi atau cara untuk mencapai ketertarikan diri, tetapi menyuguhkan kita dalam beberapa bentuk masyarakat dan memberi kita rasa saling memiliki (Putri, 2014:7).

New media memiliki kecepatan untuk melakukan sebuah interaksi, lebih efisien, lebih murah, lebih cepat untuk mendapatkan sebuah informasi terbaru dan ter-update informasinya. Kelemahannya pada jaringan koneksi internet, jika jaringan internet lancar dan cepat maka informasi yang disampaikan kepada pembacanya tiba dengan cepat. Media online/media baru masuk ke dalam kategori komunikasi massa, karena pesan yang disampaikan kepada khalayak luas lewat media online.

Definisi Media Sosial menurut Tjiptono (2016) adalah teknologi berbasis internet yang menfasilitasi percakapan. Perbedaan dengan aplikasi web tradisional adalah pada platform berupa content creation, content upload, networking, conversing, media sharing dan bookmarking.

Media sosial membawa informasi mengalir seperti air. Setiap orang dapat mengakses ribuan bahkan jutaan informasi yang dibawa oleh media sosial, seperti pada penelitian ini, menggunakan media sosial instagram.

Nama Instagram merupakan kependekan dari instant dan telegram. Seiring berjalannya waktu, Instagram telah menjadi layanan photo sharing yang andal dengan segudang prestasi dan jutaan pengguna. Setelah kesuksesan di platform iOS berhasil diraih 3 April 2012 menjadi hari bersejarah berikutnya bagi Instagram karena telah sukses mendarat di Android. Hanya berselang sembilan hari setelah kehadirannya di Android, Instagram membuat kehebohan lebih besar lagi, karena perusahaan ini dibeli oleh Facebook pada 12 April 2012 (Atmoko, 2012).

Menurut Bambang, Instagram adalah sebuah aplikasi dari Smartphone yang khusus untuk media sosial yang merupakan salah satu dari media digital yang mempunyai fungsi hampir sama dengan twitter, namun perbedaannya terletak pada pengambilan foto dalam bentuk atau tempat untuk berbagi informasi terhadap penggunanya. Instagram juga dapat memberikan inspirasi bagi penggunanya dan juga dapat meningkatkan kreatifitas, karena Instagram mempunyai fitur yang dapat membuat foto menjadi lebih indah, lebih artistik dan menjadi lebih bagus (Atmoko, 2012:10).

Iklan instagram menjadi sangat digemari setelah instagram menjadi salah satu media sosial yang paling sering diakses. Setelah 2012 diakusisi oleh Facebook, maka instagram menyediakan fitur baru yakni instagram ads atau iklan instagram yang bisa digunakan penggunanya untuk meningkatkan awareness pada akunnya maupun untuk menaikkan penjualan produk atau jasa yang ditawarkan oleh perusahaan.

Brand Thule yang dikelola oleh Bags City di Indonesia memanfaatkan sosial media Instagram sebagai media komunikasi dalam meningkatkan brand awareness. Akun Instagram @bagscityid, memiliki sekitar 4.756 followers sampai Oktober 2020.

\section{METODE PENELITIAN}

Penelitian ini menggunakan pendekatan deskriptif kualitatif. Penelitian deksriptif bertujuan untuk mengumpulkan informasi actual secara rinci dengan melukiskan gejala yang ada, mengidentifikasikan gejala yang berlaku, menentukan apa yang dilakukan orang lain dalam menghadapi masalah yang sama dan belajar dari mereka untuk mentapkan rencana dan keputusan pada waktu yang akan datang (Rahmad,2004:25).

Subjek penelitian dalam penelitian ini adalah akun Instagram @bagscityid yang hobby 
melakukan traveling yang selalu memperhatikan penampilan (lifestyle) di setiap aktivitasnya. Selain itu adalah salah satu photografer di Kota Tangerang Selatan sebagai informan, sedangkan objek dalam penelitiannya adalah produk Thule. Teknik pengumpulan data dalam penelitian ini dilakukan melalui observasi, wawancara secara mendalam kepada informan dan internet searching.

\section{HASIL PENELITIAN}

Semakin tinggi tingkat kesadaran uatu merek dalam benak konsumen, maka semakin besar kemungkinan merek tersebut dipertimbangkan dalam pembelian dan membuka peluang merek tersebut untuk dipilih oleh konsumen. Apabila dikaitkan dengan masa pandemi Covid19, tidak sedikit perusahaan yang bingung membuat strategi komunikasi pemasaran di tengah kondisi yang tidak normal ini. Tapi saat inilah perusahaan ditantang untuk bertindak kreatif sekaligus produktif.

Melihat permasalahan ini, cara produk Thule untuk tetap bertindak kreatif adalah dengan membuat konten sosial media Instagram agar produk tetap selalu ada di benak konsumen dan meningkatkan brand awareness. Penggunaan media sosial untuk meningkatkan Brand Awareness sudah tidak bisa dipungkiri. Sebab, mayoritas penduduk di Indonesia, terutama generasi milenial, saat ini adalah pengguna aktif media sosial. Alasan lain adalah efektifitas pemasaran, berbagai platform di media sosial saat ini sudah menyediakan fitur ads atau beriklan dengan sasaran dan target yang sangat spesifik, tidak terkecuali sosial media Instagram yang menyediakan fitur ads.

Informan dalam penelitian ini adalah informan yang sukses, berusia muda dan selalu memperhatikan penampilan (lifestyle) di setiap aktivitasnya. Informan 1 adalah seorang perempuan cantik, cerdas dan fashionable yang hobby traveling. Dari hasil wawancara, informan ini mengaku jika ia sudah lama menjadi penggemar Brand Thule, karena ia mengetahui kualitas dan model produknya yang simple namun elegant.

Awalnya ia mengenal brand Thule ini dari salah satu konten "Staycation" influencer Bags City. Dalam konten tersebut sang influencer memakai produk Thule ketika melakukan traveling. Konten traveling dengan staycation di tengah pandemi Covid-19 ini memang sedang banyak diperbincangkan oleh masyarakat. Masyarakat bisa melakukan traveling ke tempat yang tidak terlalu jauh atau hanya dengan menginap di hotel dan menikmati fasilitas yang disediakan oleh hotel tersebut.

Dalam foto traveling, influencer tersebut merekomendasikan tas yang ia pakai dan dalam fotonya terdapat tag akun@bagscityid, lalu informan ini memasuki halaman akun@bagscityid dan mengikutinya sampai sekarang. Informan ini mengatakan, bahwa ia sering berkomunikasi melalui direct message untuk menanyakan ketersediaan stock produk yang diinginkan.

Sementara itu Informan 2 adalah seorang lelaki muda yang berprofesi sebagai photographer di Kota Tangerang Selatan. Dari hasil wawancara, informan ini mengatakan, ia mendapatkan rekomendasi tas kamera Thule dari komunitas sepeda. Awalnya informan ini tidak mengetahui brand Thule ini menjual berbagai produk tas, koper dan aksesoris traveling lainnya, yang ia tahu brand Thule di Indonesia menjual roof box untuk mobil.

Setelah melihat temannya memakai tas kamera Thule dan merekomendasikannya untuk follow akun@bagscityid, ia pun tertarik dan mencari tahu berbagai produk Thule melalui akun Instagram@bagscityid dan berinteraksi dengan mudah melalui akun tersebut tanpa harus datang ke store offline untuk bertanya-tanya, namun dia menyampaikan keluhan jika dia memberikan komentar dalam unggahan foto produk Brand Thule yang ia suka, respon dari akun tersebut sedikit lambat.

\section{KESIMPULAN}

Kesimpulan penelitian ini adalah, konten yang diunggah di akun Instagram @bagscityid meruapakan bagian dari strategi komunikasi pemasaran dalam membangun Brand Awareness produk Thule di tengah pandemi Covid-19. Generasi milenial mengenal Brand Thule dari 
media sosial Instagram melalui salah satu influencer travel vlogger dan telah memanfaatkan direct message instagram sebagai media komunikasi. Konsumen milenial mengetahi Brand Thule dari media sosial Instagram dan memanfaatkan media sosial tersebut untuk berinteraksi di akun@bagscity.id.

Namun pengelola akun @bagscityid belum memberikan respon yang cepat kepada konsumen, baik pesan yang disampaikan melalui direct message maupun di kolom komentar unggahan. Temuan itu membuat komunikasi belum dapat berjalan dengan cepat untuk memberi rasa puas kepada konsumen atas pelayanan atau interaksi online melalui media sosial Instagram.

\section{Daftar Pustaka}

Aaker, D. (1997). Manajemen Ekuitas Merek, Jakarta: Spektrum.

Atmoko, D, (2012). Instagram Handbook Tips Fotografi Ponsel. Jakarta: Media Kita Bungin, B. (2007). Penelitian Kualitatif. Jakarta: Kencana

Diamond, S. (2015). The Visual Marketing Revolution: 26 Kuat Sukses Pemasaran di Media Sosial. Jakarta: PT Serambi Ilmu Semesta

Fandy, T., Greforius, C. (2016). Pemasaran Jasa (Prinsip, Penerapan, dan Penelitian), Yogyakarta: Andi

Kotler, P., Kartajaya, H., Setiawan, I. (2019). Marketing 4.0 Bergerak dari Tradisional Ke Digital. Jakarta: PT Gramedia Pustaka Utama

Kotler, P., Kevin, L.K. (2012). Marketing Management. Jakarta:PT. Indeks Kelompok Gramedia.

Mulyana, D. (2009). Ilmu Komunikasi; Suatu Pengantar. Bandung : Remaja Rosdakaraya

Richard, W, Lynn, H.T. (2017). Pengantar Teori Komunikasi. Jakarta: Salemba Humanika

Ruslan, R. (2010). Metode Penelitian: Public Relations dan Komunikasi. Jakarta: PT. RajaGrafindo Persada.

Tjiptono, F. (2008). Strategi Pemasaran, Yogyakarta : ANDI 